\title{
A NOVEL PROCESS FOR NUTRIENTS REMOVAL AND PHOSPHORUS RECOVERY FROM DOMESTIC WASTEWATER BY COMBINING BNR WITH INDUCED CRYSTALLIZATION
}

\author{
Haiming ZOU ${ }^{\mathrm{a}, \mathrm{b}}$, Xiwu LU, Ting $\mathrm{LI}^{\mathrm{a}}$ \\ ${ }^{a}$ School of Energy and Environment, Southeast University, Nanjing 210096, PR China \\ ${ }^{b}$ Department of Resource and Environment, Anhui Science and Technology University, \\ Fengyang 233100, PR China
}

Submitted 18 Dec. 2013; accepted 30 May 2014

\begin{abstract}
An excessive discharge of phosphorus from wastewater to water bodies may potentially contribute to eutrophication. On the other hand, mineral phosphorus resources will be depleted in the near future, because of difficulty to automatically recycle from water to land, unlike nitrogen. A new process for nutrients removal coupled with phosphorus recovery was proposed in this study by combining biological nutrients removal (BNR) with induced crystallization (IC), BNR-IC for short later, differently from conventional phosphorus recovery process. Our results showed that the BNR-IC system can maintain not only high and stable carbon, nitrogen and phosphorus removal efficiencies, all presenting above $90 \%$, but also good phosphorus recovery performance from synthetic domestic wastewater, displaying about $70.2 \%$ of phosphorus recovery rate. When the $\mathrm{COD}, \mathrm{TN}, \mathrm{NH}_{4}-\mathrm{N}$ and $\mathrm{P}$ concentrations of $250 \mathrm{mg} \mathrm{L}^{-1}, 42 \mathrm{mg} \mathrm{L}^{-1}, 40 \mathrm{mg} \mathrm{L}^{-1}$, and $10 \mathrm{mg} \mathrm{L}^{-1}$, respectively were given in the influent, a stable removal efficiencies of $92.5 \% \mathrm{COD}, 78.6 \% \mathrm{TN}, 85.9 \% \mathrm{NH}_{4}-\mathrm{N}$ and $95.2 \% \mathrm{P}$ were obtained for the BNR-IC process and correspondingly the COD, TN, $\mathrm{NH}_{4}-\mathrm{N}$ and $\mathrm{P}$ concentrations of $18.75 \mathrm{mg} \mathrm{L}^{-1}, 8.99 \mathrm{mg} \mathrm{L}^{-1}, 5.64 \mathrm{mg} \mathrm{L}^{-1}, 0.42 \mathrm{mg} \mathrm{L}^{-1}$ were monitored in the effluent, meeting the Chinese National Class I (grade A) Sewage Discharge Standard. Analyses of SEM and EDS, moreover, also demonstrated that the surface of seed crystal (calcite used here) was completely covered by hydroxyl calcium phosphate (HAP) produced during the induced crystallization process to recover phosphorus. Although our study involved only a small-scale trial, the proposed BNR-IC process here may be a promising technology, and can potentially aid in improvement of the effluent quality from WWTP and in recycle of mineral phosphorus resources when applied to practice.
\end{abstract}

Keywords: wastewater treatment, nutrients removal, phosphorus recovery, denitrifying phosphorus removal, induced crystallization, hydroxyl calcium phosphate.

\section{Introduction}

Phosphorus $(\mathrm{P})$ is an essential element for the development of biomass constituting one of the key nutrients necessary for growth. However, an excessive discharge of $\mathrm{P}$ from wastewater to water bodies may adversely affect water resources in some ways, especially potential contributions to eutrophication, which usually occurs in Taihu Lake, Chaohu Lake and Dianchi Lake, China. Removal of $\mathrm{P}$ from domestic sewage is one of the major strategies for preventing eutrophication. Therefore, legislation on $\mathrm{P}$ disposal into the water environment is becoming stricter worldwide. In Europe and North America, TP concentration of $0.1 \mathrm{mg} \mathrm{L}^{-1}$ or lower in the effluent from wastewater treatment plants (WWTP) is being required to achieve (Boltz et al. 2012). Similarly, $0.5 \mathrm{mg} \mathrm{L}^{-1}$ or lower P of effluent from WWTP is also imposed by Chinese government, compulsively meeting the National Class I (grade A) Sewage Discharge Standard (GB 18918-2002 published by State Environmental Protection Administration of China).

Moreover, the quantities of mineral phosphorus resources are rapidly decreasing in the world, presenting a global concern that $\mathrm{P}$ resources will be depleted in the near future, probably next 50-100 years (Chen et al. 2009; Takeda et al. 2010). Unlike nitrogen, $\mathrm{P}$ is not widely circulated on the globe due to the fact that flux of $\mathrm{P}$ from land to water is substantial but the reverse flux is extremely

\footnotetext{
Corresponding author: Xiwu Lu

E-mail: xiwulu@seu.edu.cn
} 
limited, only via fishery or collection of guano (Childers et al. 2011). On the other hand, there has been an increase in the global demand for $\mathrm{P}$ with the world population growing, approximately $80 \%$ of which is mostly used to produce fertilizer for agricultural activities (De-Bashan, Bashan 2004; Kröger et al. 2013). Consequently, the recovery of $P$ from wastewater is highly essential for enhancing the quality of water environment and for recycling of mineral phosphorus resources.

In recent years, studies focusing increasingly on combined processes, removing $\mathrm{P}$ from domestic wastewater and recovering it simultaneously in the form of a valuable product, such as struvite (MAP) or hydroxyl calcium phosphate (HAP), have been performed in lab-scale or full-scale reactors (Antonini et al. 2012; Cao et al. 2007; Cusick, Logan 2012; Daniels et al. 2013; Hug, Udert 2012). Most of studies have mainly focused on the combination of biological nutrients removal (BNR) with chemical precipitation process. In these processes, phosphorus in the P-rich solution generated by anaerobic sludge digestion was recovered via precipitation of MAP or HAP (Mañas et al. 2011). The disadvantages of this approach are obvious by the following two points: (a) operation of anaerobic sludge digestion performed out of biological nutrient removal process can suffer from high costs; (b) the precipitation product containing $\mathrm{P}$ with high moisture content is not easy to use directly in agricultural or industrial activities.

For this, a new process for $\mathrm{P}$ removal and recovery was proposed in this study by combining BNR with induced crystallization, BNR-IC for short here, expecting an achievement of stable and efficient carbon, nitrogen and phosphorus removal and maximum $P$ recovery simultaneously. Compared with the conventional process linking BNR with chemical precipitation, the advantages of the new process may display: (a) a P-rich supernatant generated by denitrifying polyphosphate accumulating organisms (DPAO) in the anaerobic tank, included the BNR-IC system, omitting the procedure of anaerobic sludge digestion; (b) the crystallization product can be dewatered easily and could be potentially used directly as phosphorus fertilizer or industrial raw materials; (c) moreover, the induced HAP crystallization section can greatly reduce the P loading in the anoxic environment (presenting the excessive
P uptake by DPAO), thus resulting in a minimize sludge production. Several studies have demonstrated that $\mathrm{P}$ can be removed from solution by crystallization of HAP in the presence of appropriate concentration of $\mathrm{Ca}^{2+}$ (Jang, Kang 2002; Kim et al. 2006).

Therefore, it was a hypothesized that the new process, proposed in this study, for nutrients removal and phosphorus recovery from domestic sewage by combining BNR with IC may be an effective strategy and could achieve the stable removal efficiencies of carbon, nitrogen and phosphorus, and successfully recover $P$ from domestic wastewater. The aim of this study was to demonstrate the effectiveness of the novel process by monitoring carbon, nitrogen and phosphorus removal performances using chemical analysis and investigating the crystallization product using scanning electron micrograph (SEM) and energy dispersive spectrometry (EDS). The results obtained from here may serve as a new suggestion for linking the nutrients removal with $\mathrm{P}$ recovery from domestic wastewater.

\section{Materials and methods}

\subsection{Experimental set-up and operation}

The BNR-IC (Fig. 1) consisted of biological nutrients removal system adopting a double-sludge process running in anaerobic-anoxic/aerobic described by (Peng et al. 2004) and induced crystallization column, as shown in Figure 2, was designed by us, which has been applied for a parent (No. 201110431802.4) in China. The IC column with the total working volume of $2.5 \mathrm{~L}$ consisted of reaction zone for the induced crystallization, buffer zone and settling zone for turning of seed crystal (calcite used in this study) back to reaction zone again. In addition, a calcium chloride solution was given to provide $\mathrm{Ca}^{2+}$ for the induced HAP crystallization process and air was pumped for fluidization of seed crystal in reactor zone and stripping of carbon dioxide from P-rich solution, which can increase the $\mathrm{pH}$ value, for the better of induced HAP crystallization.

In the BNR-IC system, domestic wastewater is introduced into anaerobic tank, with a working volume of 3.3 L, where $\mathrm{P}$ is released from cells of DPAO responsible for phosphorus removal and most of readily

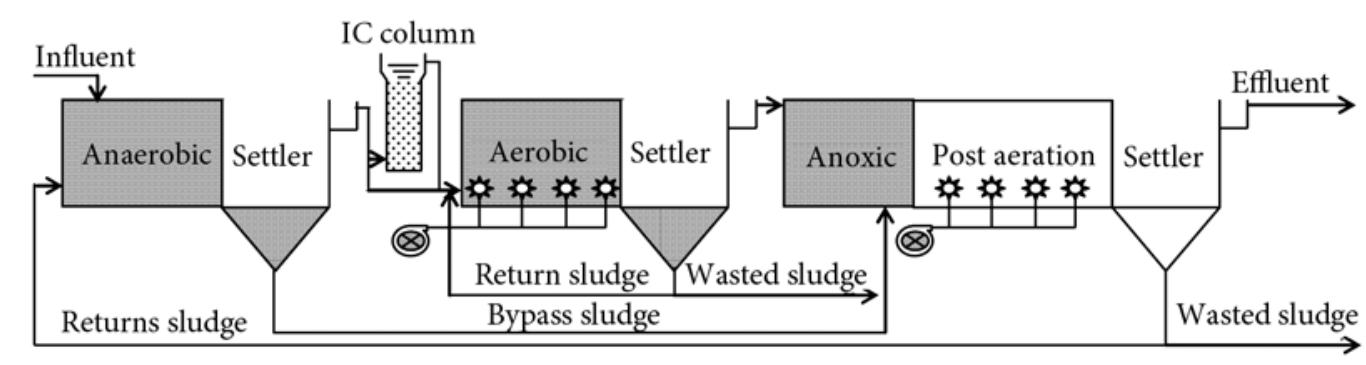

Fig. 1. Schematic diagram of combining BNR with IC process 


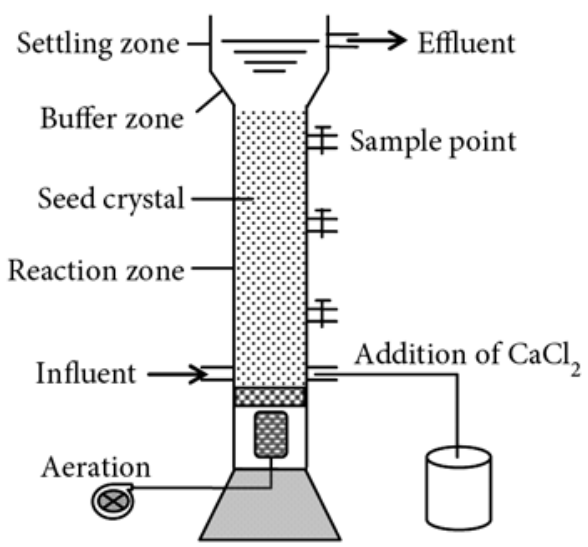

Fig. 2. Configuration of IC column

biodegradable COD is taken up and stored as poly- $\beta$ hydroxybutyrate (PHB). After settling, the P-rich supernatant is partly led into the IC column to recover $\mathrm{P}$ and the rest of that with effluent of the IC column altogether flow into aerobic tank (3.3 L) for nitrification. Sequentially, the clarified supernatant from nitrification tank is introduced into anoxic tank $(3.3 \mathrm{~L})$ for denitrifying nitrogen and phosphorus simultaneously, completed by DPAO, here presenting the excessive $\mathrm{P}$ uptake using the nitrate as electron acceptor. Lastly, a post aeration tank $(3.3 \mathrm{~L})$ is adopted for nitrogen gas stripping and the residual nutrients removal in order to ensure or enhance the quality of effluent.

The whole experiment was divided into three main phases according to the operational conditions, as described below:

Phase 1 (0 55 days): Seed sludge (collected from an aerobic basin of the Chengdong Municipal Wastewater Treatment Plant, Nanjing, China with AA-aerobic $\left(\mathrm{A}^{2} \mathrm{O}\right)$ configuration) were introduced into aerobic tank and anoxic tank respectively for enrichments of nitrification bacteria and DPAO in their respective tanks. These were preformed according to the method (Peng et al. 2004) with slight modification, in which no waste sludge was discharged from tanks in this phase to maintain a lager amount of biomass. During the enrichment of DPAO, influent concentrations of COD and P were $250 \mathrm{mg} \mathrm{L}^{-1}$, and $10 \mathrm{mg} \mathrm{L}^{-1}$, respectively in anaerobic and addition of $45 \mathrm{NO}_{3}-\mathrm{N} \mathrm{mg} \mathrm{L} \mathrm{L}^{-1}$ was conducted in anoxic, and for nitrification bacteria cultivation, that of $\mathrm{COD}, \mathrm{NH}_{4}-\mathrm{N}$ and alkalinity $\left(\mathrm{CaCO}_{3}\right)$ were $80 \mathrm{mg} \mathrm{L}^{-1}$, $40 \mathrm{mg} \mathrm{L}^{-1}$ and $120 \mathrm{mg} \mathrm{L}^{-1}$, respectively.

Phase 2 (56 85 days): The BNR-IC system proposed in this study was connected and operated continuously until the combined process reach steady nutrients removal efficiencies and $\mathrm{P}$ recovery rate, where the influent concentrations of COD, $\mathrm{TN}, \mathrm{NH}_{4}-\mathrm{N}$ and $\mathrm{P}$ were $250 \mathrm{mg} \mathrm{L}^{-1}$, $42 \mathrm{mg} \mathrm{L}^{-1}, 40 \mathrm{mg} \mathrm{L}^{-1}$, and $10 \mathrm{mg} \mathrm{L}^{-1}$, respectively. In this phase, the flow rates of influent, bypass sludge, return sludge, controlled by variable speed peristaltic pumps, were maintained at $18 \mathrm{~L} \mathrm{~d}^{-1}, 7.2 \mathrm{~L} \mathrm{~d}^{-1}$ and $7.2 \mathrm{~L} \mathrm{~d}^{-1}$, respectively. In addition, the lateral flow ratio was set at $35.0 \%$, representing that $35.0 \%$ of supernatant from anaerobic tank flowed into IC column and $65.0 \%$ of that directly into aerobic tank. Air was supplied at a flow rate of $1.5 \mathrm{~L} \mathrm{~min}^{-1}$ to meet the dissolved oxygen (DO) concentration higher than $2 \mathrm{mg} \mathrm{L}^{-1}$ at the aerobic and post-aeration tank. The mixed liquid suspended solid (MLSS) in the anaerobic tank, anoxic tank and post aeration tank were maintained at $3.4 \sim 3.6 \mathrm{~g} \mathrm{~L}^{-1}$ while that in aerobic tank was controlled at $3.0 \sim 3.2 \mathrm{~g} \mathrm{~L}^{-1}$, resulting in the SRT of nitrifying bacteria and DPAO were approximately 16 days and 12 day, respectively. Moreover, the amount of $\mathrm{Ca}^{2+}$ (calcium chloride used here) was provided into IC column following the molar ratio 2.5 of Ca to $\mathrm{P}$ to enable HAP crystallization.

Phase 3 (86 115 days): After the BNR-IC process reached the stable steady, the concentrations of carbon, nitrogen and phosphorus were investigated along the flow and induced crystallization product was recovered and analyzed by using SEM coupled with EDS, where the process parameters were given similar to the phase 2 .

\subsection{Assessment of phosphorus release and uptake capacities by DPAO}

After completing the cultivation of microorganisms, the capacities of anaerobic phosphorus release and anoxic phosphorus uptake by DPAO were assessed through a batch test under anaerobic/anoxic environments, which was conducted according to the following procedures: a) $0.5 \mathrm{~L}$ of activated sludge was taken from anoxic tank, immediately washed twice with the nutrients solution (Table 1) not containing the basic medium, and then, filled into one $1 \mathrm{~L}$ test device (transformed triangular flask); b) $0.5 \mathrm{~L}$ of synthetic wastewater was added to achieve an initial concentration of COD $250 \mathrm{mg} \mathrm{L}^{-1}, \mathrm{P} 10 \mathrm{mg} \mathrm{L}^{-1}$ for anaerobic phosphorus release; $\mathrm{c}$ ) after a $2 \mathrm{~h}$ anaerobic period, nitrogen gas was supplied in the anoxic condition for $4 \mathrm{~h}$, with the addition of $45 \mathrm{NO}_{3}-\mathrm{N} \mathrm{mg} \mathrm{L}^{-1}$ as well for providing the electron acceptor to denitrify nitrogen and phosphorus removal.

\subsection{Synthetic domestic sewage}

The synthetic domestic wastewater, composition detailed in Table 1, was fed to the BNR-IC system in this study. In phase 1, the influent concentrations of $\mathrm{COD}, \mathrm{P}$ and $\mathrm{NO}_{3}-\mathrm{N}$ were $250 \mathrm{mg} \mathrm{L}^{-1}, 10 \mathrm{mg} \mathrm{L}^{-1}$ and $45 \mathrm{mg} \mathrm{L}^{-1}$, respectively and in the phase 2 and 3, the influent concentrations of COD, $\mathrm{PO}_{4}-\mathrm{P}, \mathrm{NH}_{4}-\mathrm{N}, \mathrm{TN}$ were $250 \mathrm{mg} \mathrm{L}^{-1}, 10 \mathrm{mg} \mathrm{L}^{-1}, 40 \mathrm{mg} \mathrm{L}^{-1}$ and $42 \mathrm{mg} \mathrm{L}^{-1}$, respectively, and correspondingly the ratios of COD/P, COD/TN were 25:1, 6:1, respectively, belonging to the lower $\mathrm{C} / \mathrm{N}$ ratio wastewater similar to real domestic sewage. 
Table 1. Composition of wastewater used for experiment

\begin{tabular}{lclc}
\hline $\begin{array}{c}\text { Composition } \\
\text { of feeds }\end{array}$ & Content g/L & \multicolumn{1}{c}{$\begin{array}{c}\text { Composition of } \\
\text { nutrient solution }\end{array}$} & Content g/L \\
\hline $\mathrm{CH}_{3} \mathrm{COONa}$ & 0.322 & $\mathrm{FeCl}_{3} \cdot 6 \mathrm{H}_{2} \mathrm{O}$ & 1.50 \\
$\mathrm{KH}_{2} \mathrm{PO}_{4}$ & 0.044 & $\mathrm{H}_{3} \mathrm{BO}_{3}$ & 0.15 \\
$\left(\mathrm{NH}_{4}\right)_{2} \mathrm{SO}_{4}$ & 0.047 & $\mathrm{CuSO}_{4} \cdot 5 \mathrm{H}_{2} \mathrm{O}$ & 0.03 \\
$\mathrm{CaCl}_{2}$ & 0.005 & $\mathrm{KI}_{2}$ & 0.18 \\
$\mathrm{MgSO}_{4} \cdot 7 \mathrm{H}_{2} \mathrm{O}$ & 0.05 & $\mathrm{MnCl}_{2} \cdot 4 \mathrm{H}_{2} \mathrm{O}$ & 0.12 \\
$\mathrm{Nutrient}_{\text {solution }}$ & $0.30 \mathrm{~mL} / \mathrm{L}$ & $\mathrm{Na}_{2} \mathrm{MoO}_{4} \cdot 2 \mathrm{H}_{2} \mathrm{O}$ & 0.06 \\
& & $\mathrm{ZnSO}_{4} \cdot 7 \mathrm{H}_{2} \mathrm{O}$ & 0.12 \\
& & $\mathrm{CoCl}_{2} \cdot 6 \mathrm{H}_{2} \mathrm{O}$ & 0.15 \\
& & $\mathrm{EDTA}^{2}$ & 10.00 \\
\hline
\end{tabular}

\subsection{Analytical methods}

Samples of activated sludge and effluent from different tanks were taken regularly from the BNR-IC system. COD and MLSS were determined according to the standard methods for the examination of water and wastewater (APHA 2005). $\mathrm{PO}_{4}-\mathrm{P}, \mathrm{NH}_{4}-\mathrm{N}$ and $\mathrm{TN}$ were analyzed by segmented flow analysis (AutoAnalyzer3, SEAL, UK). DO, $\mathrm{pH}$ and Oxidation-reduction potential (ORP) were measured by a DO meter analyzer (YSI DO200, USA) and a pH and ORP meter analyzer (YSI pH100, USA).

For analysis of crystallization product, used calcite, probably covered by HAP crystal onto the surfaces of those, was collected at the end of running 30 days in the phase 3 (described above) and dried at $60{ }^{\circ} \mathrm{C}$. The treated samples were observed after spray-gold treatment, by using SEM (JSM-6360LV, Japan) coupled with EDS (GENESIS 2000 XMS, USA). For comparison purposes, raw seed crystal was also observed according to the same methods.

\section{Results and discussion}

\subsection{The performance of BNR-IC process}

Nitrifying bacteria and DPAO were successfully enriched in their respective tanks during the 55 days cultivation process. At the steady state, in the BNR-IC system, when the COD, TN, $\mathrm{NH}_{4}-\mathrm{N}$ and $\mathrm{P}$ concentrations of $250 \mathrm{mg} \mathrm{L}^{-1}$, $42 \mathrm{mg} \mathrm{L}^{-1}, 40 \mathrm{mg} \mathrm{L}^{-1}$, and $10 \mathrm{mg} \mathrm{L}^{-1}$, respectively were given in the influent, a stable removal efficiencies of 92.5\% COD, 78.6\% TN, 85.9\% $\mathrm{NH}_{4}-\mathrm{N}$ and $95.2 \% \mathrm{P}$ were obtained for the BNR process and correspondingly the COD, TN, $\mathrm{NH}_{4}-\mathrm{N}$ and $\mathrm{P}$ concentrations of $18.75 \mathrm{mg} \mathrm{L}^{-1}$, $8.99 \mathrm{mg} \mathrm{L}^{-1}, 5.64 \mathrm{mg} \mathrm{L}^{-1}, 0.42 \mathrm{mg} \mathrm{L}^{-1}$ were monitored in the effluent, meeting the Chinese National Class I (grade A) Sewage Discharge Standard.

A typical key phosphorus biochemical transformation, namely anaerobic $\mathrm{P}$ release and anoxic $\mathrm{P}$ uptake, was observed through a cycle batch test $(2 \mathrm{~h}$ of anaerobic and $4 \mathrm{~h}$ anoxic) performed at the end of 55 days, as shown in Figure 3 . The variations of carbon, nitrogen and phosphorus concentrations during a whole anaerobic-anoxic cycle were similar to what is typically observed in EBPR systems (Podedworna, Żubrowska-Sudoł 2012), strongly suggesting that DPAO was predominant in the BNR-IC process. In this process, the anaerobic $\mathrm{P}$ release rate and anoxic $\mathrm{P}$ uptake rate were $8.47 \mathrm{mg} \mathrm{P}(\mathrm{g} \mathrm{MLSS})^{-1}$ and $11.13 \mathrm{mg} \mathrm{P}$ (g MLSS) $^{-1}$, presenting a good $\mathrm{P}$ biochemical transfer performance indicated by the ratio of anoxic $\mathrm{P}$ uptake to anaerobic $\mathrm{P}$ release (1.3), thereby creating a preferable condition that could support the growth of DPAO in the BNR-IC system (Guerrero et al. 2012a). Figure 3 shows that throughout the $6 \mathrm{~h}$-long batch test, there were a gradual decrease in COD concentration during the anaerobic phase with the increase of $\mathrm{P}$ concentration and a rapidly decline in nitrate concentration under the anoxic condition with the $\mathrm{P}$ removal simultaneously. Moreover, the significantly positive correlations between COD consumption and $\mathrm{P}$ release under anaerobic condition with 0.9972 of $\mathrm{R}^{2}$, and between nitrate removal and $\mathrm{P}$ uptake in the anoxic mode ( $\mathrm{R}^{2}$ of 0.9874$)$ also demonstrated that DPAO was dominant in the tanks included the BNR-IC system. These results are consistent with previous reports (Wang et al. 2010; Guerrero et al. 2012b; Lanham et al. 2013) which suggested the existence of significantly positive correlations between anaerobic COD consumption and $\mathrm{P}$ release, anoxic nitrate removal and $\mathrm{P}$ uptake.

Compared with DPAO, nitrification bacteria can easily be cultivated in the aerobic tank due to the fact that seed sludge collected from an aeration pond of $\mathrm{A}^{2} \mathrm{O}$ process had a high capacity for nitrification, displaying the $78.5 \%$ of $\mathrm{NH}_{4}-\mathrm{N}$ removal efficiency. At the 25th days from

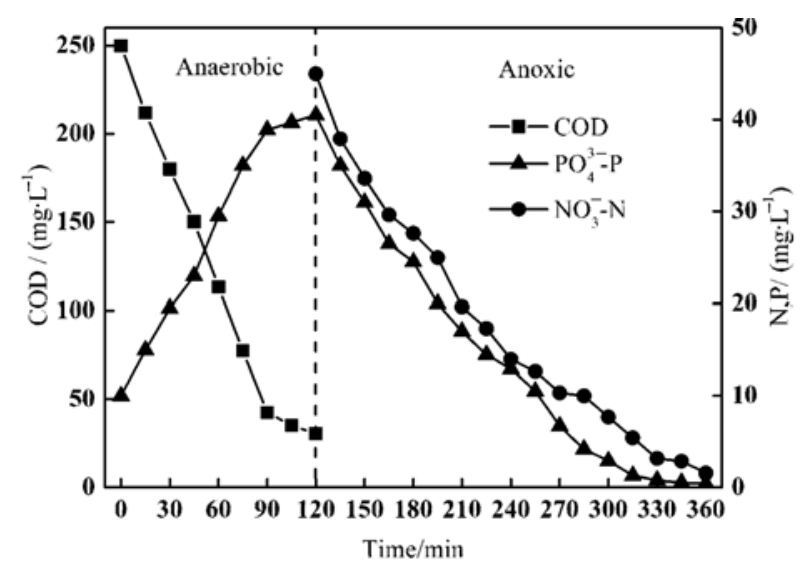

Fig. 3. Variations of carbon, nitrogen and phosphorus concentrations during a whole anaerobic-anoxic cycle 
the beginning of cultivation, the $\mathrm{NH}_{4}-\mathrm{N}$ removal efficiency reached above 95\%, suggesting that enrichment of aerobic microorganisms may be easier than that of anaerobic microbe in WWTP.

\subsection{Performance of BNR-IC process in each stage}

In the phase 3, as described section 1.1, 30 days continuous operation was performed for investigating nutrients removal efficiencies and $\mathrm{P}$ recovery rate in each tank along the flow. A stable and good performance of nutrients removal and $\mathrm{P}$ recovery was obtained in this phase, and the variations of $\mathrm{COD}, \mathrm{TN}, \mathrm{NH}_{4}-\mathrm{N}, \mathrm{NO}_{3}-\mathrm{N}$ and $\mathrm{P}$ concentrations in the effluent of different tanks along the flow in the BNR-IC process were shown Figure 4 and Table 2, respectively, and carbon, nitrogen and phosphorus removal efficiencies in each stage contributions to that in the total BNR-IC system were illustrated in Figure 5, where the negative values indicated that nutrients in this stage were not removed but produced by microbes.

As shown in Figure 5, the COD removal efficiency in anaerobic tank was significantly higher than that in other tanks, accounting for $85.9 \%$ of total COD removal rate (92.5\%) in the BNR-IC system, which is agreement well with the characteristic of DPAO (Acevedo et al. 2012). In anaerobic condition, carbon source, especially VFA, was taken up by DPAO and stored them as $\mathrm{PHB}$, resulting in the $\mathrm{P}$ release from the cells of DPAO. So there was a linear relationship between COD consumption and $\mathrm{P}$ release in the anaerobic condition, demonstrated by the results (described in Section 2.1) obtained in this study and (Chuang et al. 2011).

It should be noted that the COD concentration in the effluent from anoxic tank was more than that from aerobic tank, presenting $41.00 \mathrm{mg} \mathrm{L}^{-1}$ and $14.25 \mathrm{mg} \mathrm{L}^{-1}$ (Fig. 4 and Table 2), respectively. Consistently, the removal efficiencies of COD in anoxic tank and aerobic tank were $-11.6 \%$ and $16.0 \%$, respectively (Fig. 5). It may be explained that a portion of COD in anaerobic tank was introduced into anoxic tank via the bypass sludge return from anaerobic tank to anoxic tank, thus leading to the increase of COD concentration in anoxic tank. There is a growth competition between DPAO and denitrifying bacteria when carbon sources provided in anoxic condition (Guerrero et al. 2011). Thereby creating a lower ratio of bypass sludge may support the growth of DPAO in anoxic tank. Although the COD concentration in the effluent from anoxic tank in the BNR-IC process proposed in this study increased slightly, the residual COD can mostly be biodegraded in the post-aeration tank (contributing to $9.6 \%$ of total COD removal efficiency found here). Generally, the post-aeration tank was often used as the key equipment for further nutrients removal and discharge to meet standard (Kapagiannidis et al. 2011; Smidt, Parravicini 2009; Zafiriadis et al. 2012), thus resulting in enhancement of water quality of effluent before discharge to water bodies.

In this BNR-IC system proposed here, $\mathrm{NH}_{4}-\mathrm{N}$ removal mainly occurred in the aerobic tank, accounting for $95.4 \%$ of total $\mathrm{NH}_{4}-\mathrm{N}$ removal efficiency, while TN and $\mathrm{NO}_{3}-\mathrm{N}$ were mostly removed in the anoxic phase, as shown in Table 2, Figure 4 and Figure 5, respectively, indicating that good nitrification and denitrifying nitrogen and phosphorus removal simultaneously performances were present in their respective tanks.

Similar to COD concentration variation in the each stage of the BNR-IC process, there was a significant increase in $\mathrm{NH}_{4}-\mathrm{N}$ concentration in the anoxic tank compared to that in the aerobic tank, $10.03 \mathrm{mg} \mathrm{L}^{-1}$ and $0.92 \mathrm{mg} \mathrm{L}^{-1}$, respectively, probably also resulting from the sludge bypass return. The residual $\mathrm{NH}_{4}-\mathrm{N}$ can be mostly removed in the post-aeration tank, thus ensuring that the $\mathrm{NH}_{4}-\mathrm{N}$ concentration in the final effluent was about or less than $5 \mathrm{mg} \mathrm{L}^{-1}$ throughout the running period. The design of a post-aeration tank placed after a wastewater treatment process can effectively remove residue organic substances, nitrogen and phosphorus compound, thereby may further enhancing effluent quality (Zhang et al. 2013).

Considerable $\mathrm{NO}_{3}-\mathrm{N}$ or TN was removed in anoxic tank, as given in Table 2 and Figure 5, respectively. At the same time, the previously stored $\mathrm{PHB}$ was used as the carbon resources, namely electron donor, utilized by DPAO for denitrifying nitrogen and phosphorus removal simultaneously (Coats et al. 2011). Also, post-aeration contributed to low concentrations of $\mathrm{NO}_{3}-\mathrm{N}$ and $\mathrm{TN}$ in the effluent.

Table 2. Concentrations of carbon, nitrogen and phosphorus along the flow in BNR-IC

\begin{tabular}{|c|c|c|c|c|c|c|c|}
\hline & Influent & Anaerobic & & Aerobic & & Anoxic & Post-aeration \\
\hline $\mathrm{COD} / \mathrm{mg} \mathrm{L}^{-1}$ & 250.00 & 51.25 & & 14.25 & & 41.00 & 18.75 \\
\hline $\mathrm{TN} / \mathrm{mg} \mathrm{L}^{-1}$ & 42.00 & 32.17 & & 28.77 & & 9.95 & 8.99 \\
\hline $\mathrm{NH}_{4}-\mathrm{N} / \mathrm{mg} \mathrm{L}^{-1}$ & 40.00 & 31.70 & & 0.92 & & 10.03 & 5.64 \\
\hline \multirow[t]{2}{*}{$\mathrm{NO}_{3}-\mathrm{N} / \mathrm{mg} \mathrm{L}^{-1}$} & 0.58 & 0.51 & & 22.70 & & 1.95 & 4.82 \\
\hline & Influent & Anaerobic & IC & Aerobic (in) & Aerobic (out) & Anoxic & Post-aeration \\
\hline $\mathrm{P} / \mathrm{mg} \mathrm{L}^{-1}$ & 10.00 & 28.31 & 8.25 & 21.29 & 20.37 & 0.84 & 0.42 \\
\hline
\end{tabular}


Figure 4 shows the variation of $\mathrm{P}$ concentration in each stage of BNR-IC system. In anaerobic tank, a good $\mathrm{P}$ release performance conducted by DPAO was found, in which the $\mathrm{P}$ concentration in the mixed liquor rapidly increased. However, there was a significant difference in amount of anaerobic $P$ release between BNR-IC and BNR, ranging from $10.00 \mathrm{mg} \mathrm{L}^{-1}$ to $28.31 \mathrm{mg} \mathrm{L}^{-1}$ in BNR-IC lower than that in BNR (from $10.00 \mathrm{mg} \mathrm{L}^{-1}$ to $40.95 \mathrm{mg}$
$\mathrm{L}^{-1}$, as illustrated in Fig. 3). This was due to the fact that Poly-p stored in the DPAO decreased when IC column was coupled with BNR process. A part of $\mathrm{P}$ released by DPAO in anaerobic condition was recovered via induced HAP crystallization in IC column, thus leading to the reduction of $\mathrm{P}$ uptake (stored as Poly-p) in anoxic environment and subsequently $\mathrm{P}$ release (hydrolysis of Poly-p) in anaerobic condition. After 30 days running, a new balance

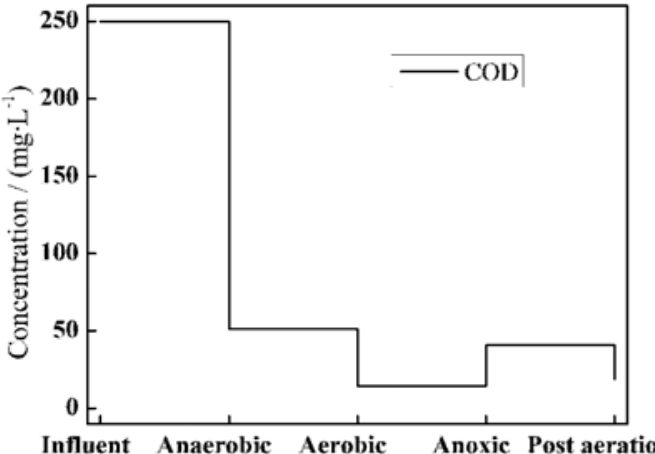

(a)

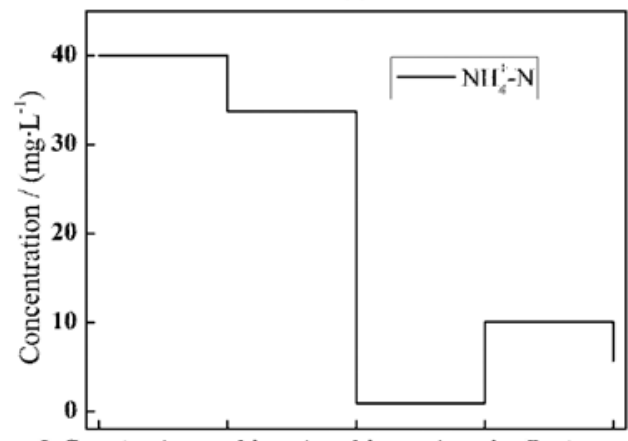

Influent Anaerobic Aerobic

(c)

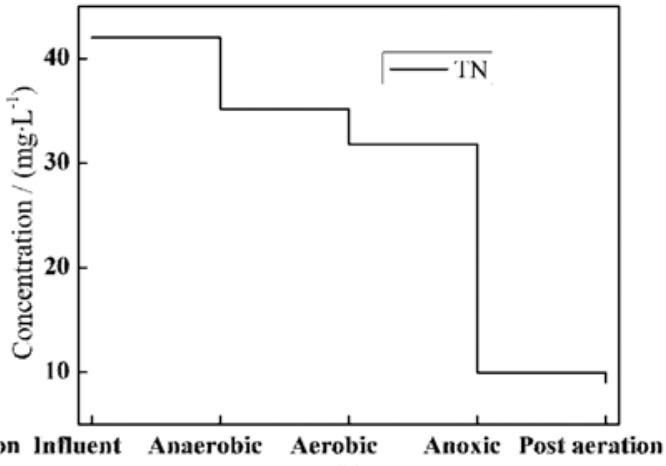

(b)

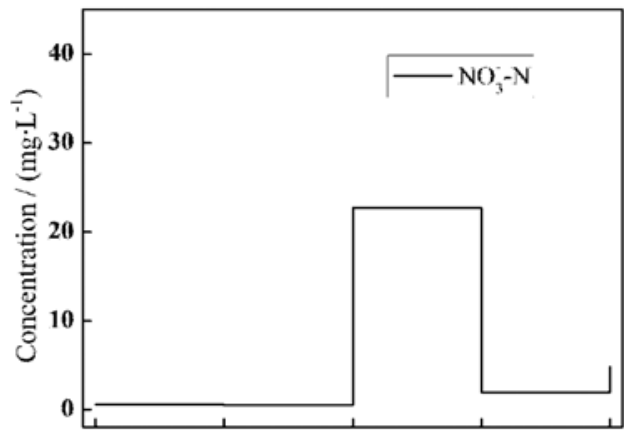

(d)

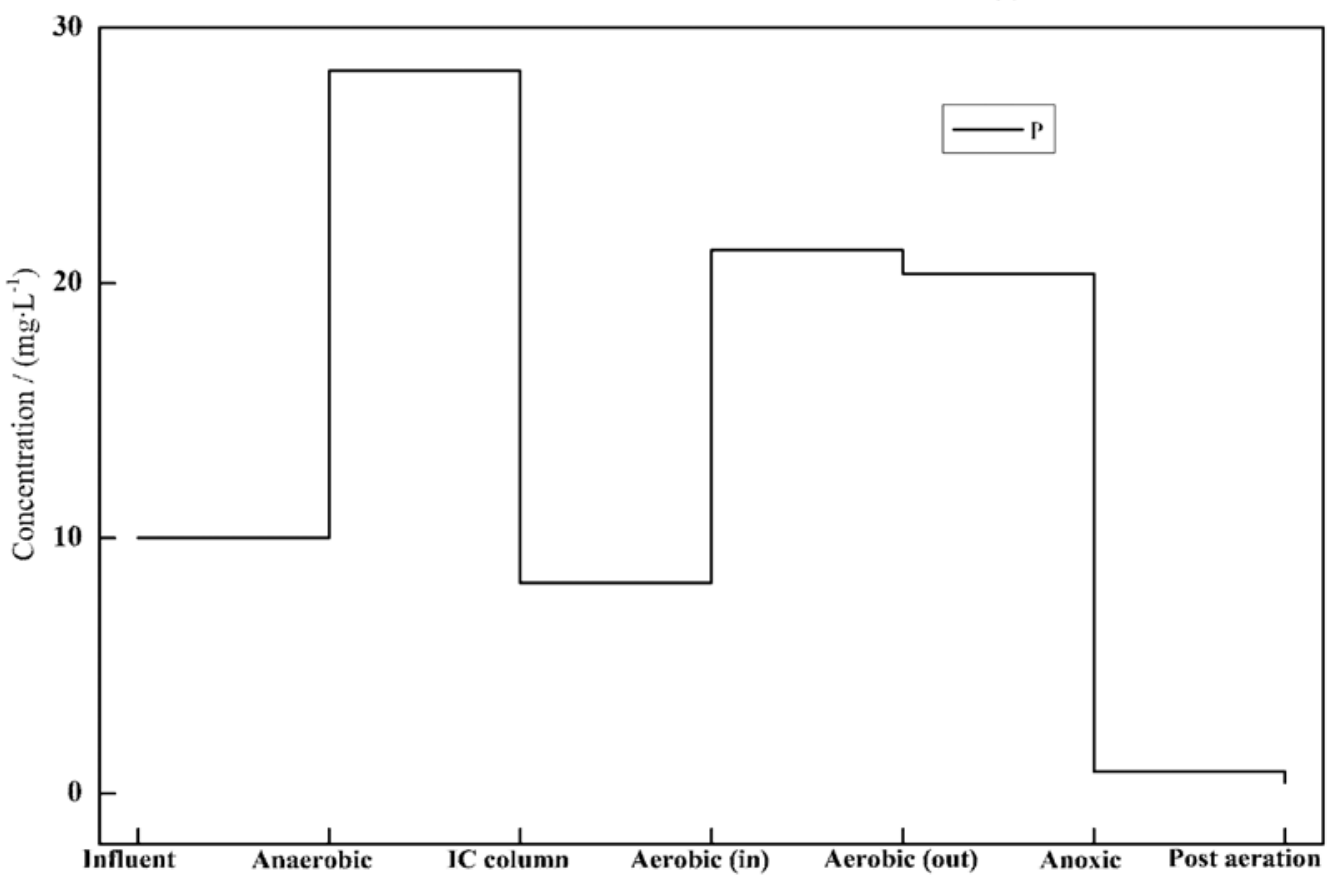

(e)

Fig. 4. Variation of carbon, nitrogen and phosphorus concentrations in each phase of BNR-IC process 


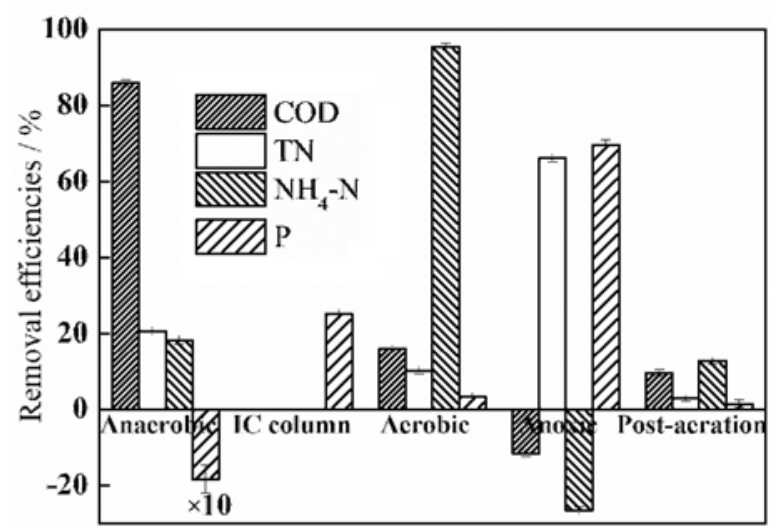

Fig. 5. Contributions to removal of carbon, nitrogen and phosphorus in each phase of BNR-IC process

among anaerobic $\mathrm{P}$ release, $\mathrm{P}$ recovery and anoxic $\mathrm{P}$ uptake was found in the new BNR-IC system proposed in this study. Although the IC column was introduced into the BNR leaded to the reduction of Poly-p stored in cells, the BNR-IC system still displayed a good characteristic of denitrifying nitrogen and phosphorus simultaneously when the lateral flow ratio was $35.0 \%$. It was noteworthy that determination of the maximum lateral flow ratio should follow the principle that normal biological performance of denitrifying nitrogen and phosphorus simultaneously in BNR-IC system cannot be damaged when maximizing the $\mathrm{P}$ recovery efficiency.

In the IC column, $70.9 \%$ of $\mathrm{P}$ recovery rate was calculated according to the $\mathrm{P}$ concentration of in the influent (28.31 $\left.\mathrm{mg} \mathrm{L}^{-1}\right)$ and effluent $\left(8.25 \mathrm{mg} \mathrm{L}^{-1}\right)$ of the reactor when the lateral flow ratio was $35.0 \%$, namely that $35.0 \%$ of supernatant from anaerobic tank flowed into IC column and the rest $65.0 \%$ of that directly into aerobic tank, thus leading to $21.29 \mathrm{mg} \mathrm{L}^{-1}$ of $\mathrm{P}$ concentration in the influent of aerobic tank.

Based on the content of $\mathrm{P}$ in mixed liquor after anaerobic P release, about $69.7 \%$ of total $\mathrm{P}$ removal in BNR-IC system occurred in anoxic tank with $66.1 \% \mathrm{TN}$ consumption (Table 2 and Fig. 5), obviously completed by DPAO performing denitrifying nitrogen and phosphorus removal simultaneously, which is agreement with the appearance in various EBPR systems (Fang et al. 2012; Marcelino et al. 2009; Slater et al. 2010), indicating that a good $\mathrm{P}$ uptake performance was also existent in the BNR-IC system. This result further demonstrated that combing BNR with IC proposed in this study was feasible for nutrients removal and $P$ recovery simultaneously from domestic wastewater.

According to the P removal performance in the IC column described above, about $70.2 \%$ of $\mathrm{P}$ in the domestic wastewater $\left(10 \mathrm{mg} \mathrm{L}^{-1}\right.$ given in this study) was recovered depending on the induced HAP crystallization in the BNR-IC system, namely about $7 \mathrm{~g}$ P per ton wastewater recovered. Compared with well known $\mathrm{P}$ recovery process of PhoStrip (Bertanza et al. 2013), where the P-rich solution is generated by anaerobic treatment of only a part of return activated sludge through the addition of external carbon source such as acetic acid and then $\mathrm{P}$ is recovered with chemical precipitation via the adding of lime, the BNR-IC process was designed to recovery $\mathrm{P}$ from the supernatants (including influent and total return sludge anaerobic treatment) by induced crystallization, where directly used the carbon sources in the influent as the electron donor for DPAO anaerobic P release, thereby exhibiting a better significant economic and environmental benefits.

\subsection{Crystallization product investigation}

To investigate the physicochemical changes of surfaces of seed crystal (calcite used in this study) before and after induced HAP crystallization, microscopic analyses were conducted by using SEM and EDS, as illustrated in Fig. 6 . There was a significant difference in the surface of calcite between before (Fig. 6a) and after (Fig. 6c) induced HAP crystallization, where the surface of used calcite was coarse greater than that in raw calcite. The SEM micrograph in Figure $6 c$ revealed that the surface of calcite was covered with a finely distributed crystallization product layer, which was regarded as HAP according to the EDS analysis. The EDS analyses demonstrated that the crystallization layer consisted predominantly of $\mathrm{O}, \mathrm{P}$ and $\mathrm{Ca}$, as depicted in Figure $6 \mathrm{~d}$, with a $\mathrm{Ca} / \mathrm{P}$ molar ratio of 1.79 slightly higher than that of 1.67 in theoretical value for HAP, which might be affected by the $\mathrm{CaCO}_{3}$ formation. Figure $6 \mathrm{~d}$ shows that carbon content obviously increased in the crystallization layer compared with the raw seed crystal, suggesting the formation of HAP crystallization with the $\mathrm{CaCO}_{3}$ production, which are in accordance with the reported studies (Barca et al. 2012; Jang, Kang 2002; Johansson, Gustafsson 2000). The formation of $\mathrm{CaCO}_{3}$ involved the consumption of $\mathrm{Ca}^{2+}$, thus leading to molar ratios of Ca reduction to $\mathrm{P}$ reduction higher than 1.67 (Barca et al. 2012).

To investigate the growth of HAP in the surface calcite during the induced crystallization process, the amount of calcite before and after this process in IC column was measured in a long-term test of 120 days. The initial calcite at a dosage of $60 \mathrm{mg} \mathrm{L}^{-1}$ occupied about $6.5 \%$ of the IC volume. At the end of 120 days running, the volume of calcite increased significantly, accounting for $12 \%$ of the total IC volume due to the HAP production during the induced crystallization process.

\section{Conclusions}

1. This study showed that the new BNR-IC system combining biological nutrients removal with induced crystallization proposed here was an effective strategy for carbon, nitrogen and phosphorus removal and P recovery 
a)

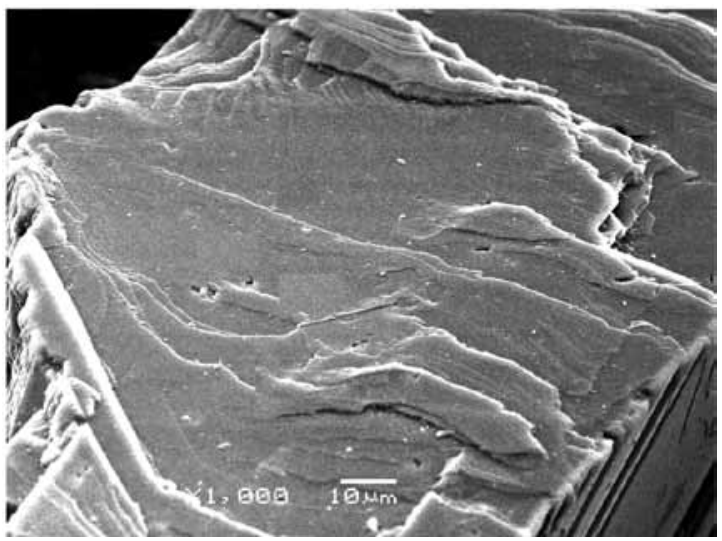

c)

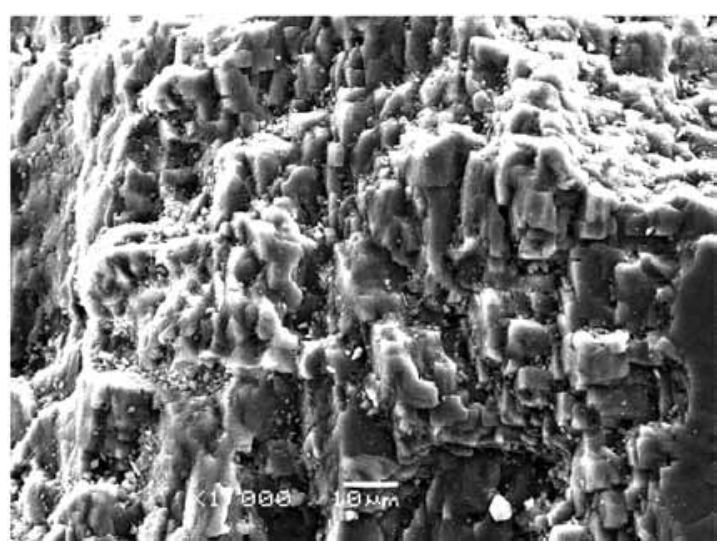

b)

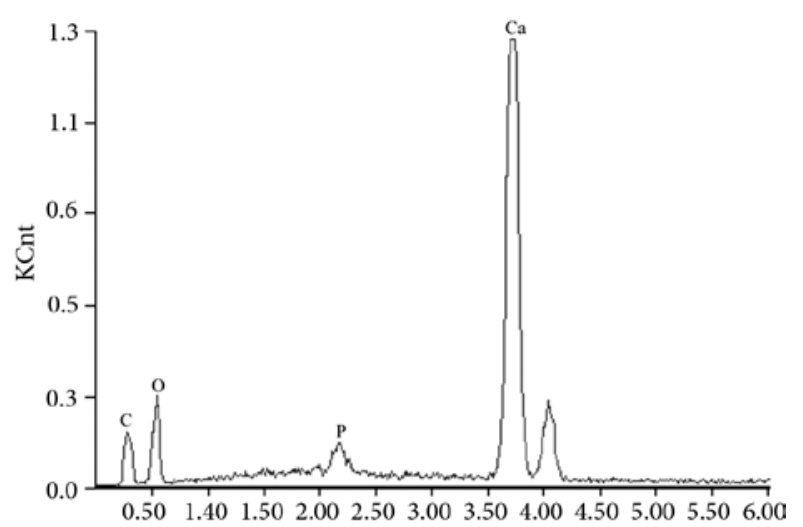

d)

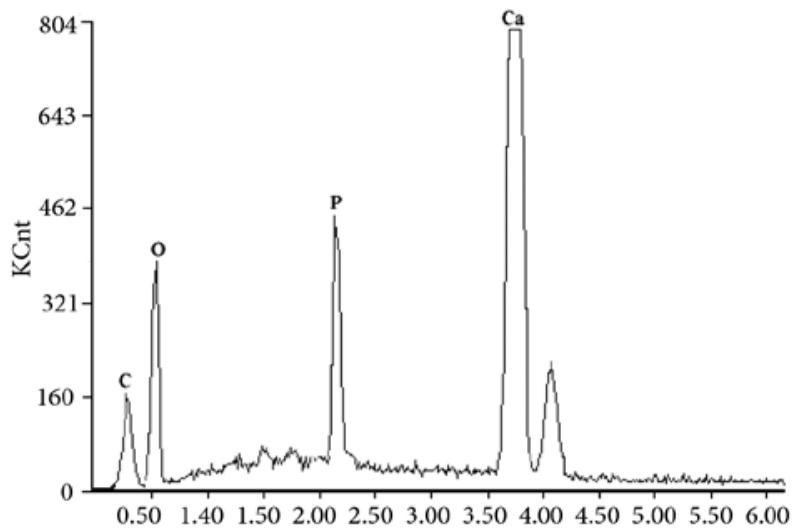

Fig. 6. SEM observation and EDS analyses of seed crystal before and after induced P crystallization: a) surface of seed crystal before $P$ recovery; b) chemical analysis of seed crystal before P recovery; c) surface of seed crystal after P recovery at the 30th days; d) chemical analysis of seed crystal after P recovery at the 30th days

from domestic wastewater, exhibiting a good performance of denitrifying nitrogen and phosphorus removal simultaneously coupled with HAP crystallization.

2. In the BNR-IC system, the removal efficiencies of COD, $\mathrm{TN}, \mathrm{NH}_{4}-\mathrm{N}$ and $\mathrm{P}$ were maintained at about $90 \%, 78 \%$, $85 \%$ and $95 \%$, respectively and $\mathrm{P}$ recovery rate achieved $70.2 \%$ via induced HAP crystallization.

3. From these results, the proposed BNR-IC system, probably being a promising technology, can potentially aid in improvement of the effluent quality from WWTP and in recycle of mineral phosphorus resources. However, future research is necessary to focus on the optimization of operation parameters and practical applications of crystallization product.

\section{Acknowledgments}

We wish to thank M.M.SU for assistance with activated sludge treatment and Dr. Li for enlightening discussion. This research is supported by grant 2012ZX07101-005 from National Key Technology in Water Pollution Control and Treatment in 12th Five-year Plan of China and grant 51078074 from National Natural Science Foundation of China.

\section{References}

Acevedo, B.; Oehmen, A.; Carvalho, G.; Seco, A.; Borras, L.; Barat, R. 2012. Metabolic shift of polyphosphate-accumulating organisms with different levels of polyphosphate storage, Water Research 46(6): 1889-1900.

http://dx.doi.org/10.1016/j.watres.2012.01.003

APHA. 2005. Standard methods for the examination of water and wastewater. 20th ed. American Public Health Association, American Water Works Association and Water Environment Federation, Washington, DC.

Antonini, S.; Arias, M. A.; Eichert, T.; Clemens, J. 2012. Greenhouse evaluation and environmental impact assessment of different urine-derived struvite fertilizers as phosphorus sources for plants, Chemosphere 89(10): 202-1210. http://dx.doi.org/10.1016/j.chemosphere.2012.07.026

Barca, C.; Gérente, C.; Meyer, D.; Chazarenc, F.; Andrès, Y. 2012. Phosphate removal from synthetic and real wastewater using steel slags produced in Europe, Water Research 46(7): 23762384. http://dx.doi.org/10.1016/j.watres.2012.02.012

Bertanza, G.; Pedrazzani, R.; Manili, L.; Menoni, L. 2013. Bio-P release in the final clarifiers of a large WWTP with coprecipitation: key factors and troubleshooting, Chemical Engineering Journal 230(15): 195-201. http://dx.doi.org/10.1016/j.cej.2013.06.067

Boltz, J. P.; Morgenroth, E.; Daigger, G. T.; DeBarbadillo, C.; Murthy, S.; Sørensen, K. H.; Stinson, B. 2012. Method to identify potential phosphorus rate-limiting conditions in 
post-denitrification biofilm reactors within systems designed for simultaneous low-level effluent nitrogen and phosphorus concentrations, Water Research 46(19): 6228-6238.

http://dx.doi.org/10.1016/j.watres.2012.08.020

Cao, X.; Harris, W. G.; Josan, M. S.; Nair, V. D. 2007. Inhibition of calcium phosphate precipitation under environmentally-relevant conditions, Science of The Total Environment 383(1-3): 205-215.

http://dx.doi.org/10.1016/j.scitotenv.2007.05.012

Chen, X.; Kong, H.; Wu, D.; Wang, X.; Lin, Y. 2009. Phosphate removal and recovery through crystallization of hydroxyapatite using xonotlite as seed crystal, Journal of Environmental Sciences 21(5): 575-580.

http://dx.doi.org/10.1016/S1001-0742(08)62310-4

Childers, D. L.; Corman, J.; Edwards, M.; Elser, J. J. 2011. Sustainability challenges of phosphorus and food: solutions from closing the human phosphorus cycle, Bioscience 61(2): 117-124. http://dx.doi.org/10.1525/bio.2011.61.2.6

Chuang, S.; Chang, W.; Huang, Y.; Tseng, C.; Tai, C. 2011. Effects of different carbon supplements on phosphorus removal in low C/P ratio industrial wastewater, Bioresource Technology 102(9): 5461-5465. http://dx.doi.org/10.1016/j.biortech.2010.11.118

Coats, E. R.; Watkins, D. L.; Brinkman, C. K.; Loge, F. J. 2011. Effect of anaerobic HRT on biological phosphorus removal and the enrichment of phosphorus accumulating organisms, Water Environment Research 83(5): 461-469. http://dx.doi.org/10.2175/106143010X12851009156402

Cusick, R. D.; Logan, B. E. 2012. Phosphate recovery as struvite within a single chamber microbial electrolysis cell, Bioresource Technology 107: 110-115. http://dx.doi.org/10.1016/j.biortech.2011.12.038

Daniels, Y.; Zhu, X.; Alexandratos, S. D. 2013. Distinguishing between organic and inorganic phosphorus in hydroxyapatite by elemental analysis, Microchemical Journal 110: 263-265. http://dx.doi.org/10.1016/j.microc.2013.04.005

De-Bashan, L. E.; Bashan, Y. 2004. Recent advances in removing phosphorus from wastewater and its future use as fertilizer (1997-2003), Water Research 38(19): 4222-4246. http://dx.doi.org/10.1016/j.watres.2004.07.014

Fang, J.; Sun, P.; Xu, S.; Luo, T.; Lou, J.; Han, J.; Song, Y. 2012. Impact of $\mathrm{Cr}$ (VI) on $\mathrm{P}$ removal performance in enhanced biological phosphorus removal (EBPR) system based on the anaerobic and aerobic metabolism, Bioresource Technology 121: 379-385. http://dx.doi.org/10.1016/j.biortech.2012.07.001

Guerrero, J.; Guisasola, A.; Baeza, J. A. 2011. The nature of the carbon source rules the competition between $\mathrm{PAO}$ and denitrifiers in systems for simultaneous biological nitrogen and phosphorus removal, Water Research 45(16): 4793-4802. http://dx.doi.org/10.1016/j.watres.2011.06.019

Guerrero, J.; Tayà, C.; Guisasola, A.; Baeza, J. A. 2012a. Understanding the detrimental effect of nitrate presence on EBPR systems: effect of the plant configuration, Journal of Chemical Technology and Biotechnology 87(10): 1508-1511. http://10.1002/jctb.3812

Guerrero, J.; Taya, C.; Guisasola, A.; Baeza, J. A. 2012b. Glycerol as a sole carbon source for enhanced biological phosphorus removal, Water Research 46(9): 2983-2991.

http://dx.doi.org/10.1016/j.watres.2012.02.043
Hug, A.; Udert, K. M. 2012. Struvite precipitation from urine with electrochemical magnesium dosage, Water Research 47(1): 289-299. http://dx.doi.org/10.1016/j.watres.2012.09.036

Jang, H.; Kang, S. 2002. Phosphorus removal using cow bone in hydroxyapatite crystallization, Water Research 36(5): 13241330. http://dx.doi.org/10.1016/S0043-1354(01)00329-3

Johansson, L.; Gustafsson, J. P. 2000. Phosphate removal using blast furnace slags and opoka-mechanisms, Water Research 34(1): 259-265. http://dx.doi.org/10.1016/S0043-1354(99)00135-9

Kapagiannidis, A. G.; Zafiriadis, I.; Aivasidis, A. 2011. Upgrading the efficiency of an external nitrification BNR system the modified Dephanox process, Chemical Engineering Journal 175: 124-135. http://dx.doi.org/10.1016/j.cej.2011.09.080

Kim, E.; Yim, S.; Jung, H.; Lee, E. 2006. Hydroxyapatite crystallization from a highly concentrated phosphate solution using powdered converter slag as a seed material, Journal of Hazardous Materials 136(3): 690-697.

http://dx.doi.org/10.1016/j.jhazmat.2005.12.051

Kröger, R.; Dunne, E. J.; Novak, J.; King, K. W.; McLellan, E.; Smith, D. R.; Strock, J.; Boomer, K.; Tomer, M.; Noe, G. B. 2013. Downstream approaches to phosphorus management in agricultural landscapes: regional applicability and use, Science of The Total Environment 442: 263-274. http://dx.doi.org/10.1016/j.scitotenv.2012.10.038

Lanham, A. B.; Oehmen, A.; Saunders, A. M.; Carvalho, G.; Nielsen, P. H.; Reis, M. A. 2013. Metabolic versatility in fullscale wastewater treatment plants performing enhanced biological phosphorus removal, Water Research 47(19): 70327041. http://dx.doi.org/10.1016/j.watres.2013.08.042

Mañas, A.; Biscans, B.; Spérandio, M. 2011. Biologically induced phosphorus precipitation in aerobic granular sludge process, Water Research 45(12): 3776-3786. http://dx.doi.org/10.1016/j.watres.2011.04.031

Marcelino, M.; Guisasola, A.; Baeza, J. A. 2009. Experimental assessment and modelling of the proton production linked to phosphorus release and uptake in EBPR systems, Water Research 43(9): 2431-2440. http://dx.doi.org/10.1016/j.watres.2009.03.003

Peng, Y.; Wang, Y.; Ozaki, M.; Pan, M. 2004. Denitrifying phosphorus removal in a continuously-flow $\mathrm{A}^{2} \mathrm{~N}$ two-sludge process, Journal of Environmental Science and Health, Part A 39(3): 703-715. http://dx.doi.org/10.1081/ESE-120027736

Podedworna, J.; Żubrowska-Sudoł, M. 2012. Nitrogen and phosphorus removal in a denitrifying phosphorus removal process in a sequencing batch reactor with a forced anoxic phase, Environmental Technology 33(2): 237-245. http://dx.doi.org/10.1080/09593330.2011.563428

Slater, F. R.; Johnson, C. R.; Blackall, L. L.; Beiko, R. G.; Bond, P. L. 2010. Monitoring associations between cladelevel variation, overall community structure and ecosystem function in enhanced biological phosphorus removal (EBPR) systems using terminal-restriction fragment length polymorphism (T-RFLP), Water Research 44(17): 4908-4923. http://dx.doi.org/10.1016/j.watres.2010.07.028

Smidt, E.; Parravicini, V. 2009. Effect of sewage sludge treatment and additional aerobic post-stabilization revealed by infrared spectroscopy and multivariate data analysis, Bioresource Technology 100(5): 1775-1780. http://dx.doi.org/10.1016/j.biortech.2008.10.003 
Takeda, I.; Somura, H.; Mori, Y. 2010. Recovery of phosphorus from natural water bodies using iron-oxidizing bacteria and woody biomass, Ecological Engineering 36(8): 1064-1069. http://dx.doi.org/10.1016/j.ecoleng.2010.04.019

Wang, Y.; Jiang, F.; Zhang, Z.; Xing, M.; Lu, Z.; Wu, M.; Yang, J.; Peng, Y. 2010. The long-term effect of carbon source on the competition between polyphosphorus accumulating organisms and glycogen accumulating organism in a continuous plug-flow anaerobic/aerobic (A/O) process, Bioresource Technology 101(1): 98-104.

http://dx.doi.org/10.1016/j.biortech.2009.07.085
Zafiriadis, I.; Ntougias, S.; Mirelis, P.; Kapagiannidis, A. G.; Aivasidis, A. 2012. Molecular characterization of denitrifying bacteria isolated from the anoxic reactor of a modified Dephanox plant performing enhanced biological phosphorus removal, Water Environment Research 84(6): 475-484. http://dx.doi.org/10.2175/106143012X13280358613543

Zhang, W.; Peng, Y.; Ren, N.; Liu, Q.; Chen, Y. 2013. Improvement of nutrient removal by optimizing the volume ratio of anoxic to aerobic zone in AAO-BAF system, Chemosphere 93(11): 2859-2863.

http://dx.doi.org/10.1016/j.chemosphere.2013.08.047

Haiming ZOU. Dr, School of Energy and Environment, Southeast University; Department of Resource and Environment, Anhui Science and Technology University. He is the author of 29 publications and has participated in 12 conferences. His research interests include nitrogen and phosphorus removal from wastewater.

Xiwu LU. Dr, Professor, School of Energy and Environment, Southeast University. He is the author of 195 publications and has participated in 89 conferences. His research interests include nitrogen and phosphorus removal from wastewater; lake pollution control.

Ting LI. Master, School of Energy and Environment, Southeast University. He is the author of 3 publications and has participated in 2 conferences. His research interests include nitrogen and phosphorus removal from wastewater. 